Department of Anatomy (Prof. T. MitsuI), Keio University School of Medicine,

Shinjuku, Tokyo

\title{
Some Observations on the Cytochemical Reaction of Oxidative Enzymes*
}

\author{
Tadao Mitsui and Toshio Shinoda \\ （三井但夫と篠田俊雄）
}

Received May 22, 1966

The oxidative enzyme reactions such as Nadi reaction and peroxidase reaction, have been widely used in the study of the morphology of leukocytes. However, there are various problems concerning the improvement of cytochemical technics for the oxidative enzymes.

The present study deals with inhibition tests, solubility of reaction end-preduct, and leuco-eosin method. The authors expect that the data obtained here will give some informations for the improvement in cytochemical technics of oxidative enzymes.

\section{Materials and Methods}

For materials blood cells of man, salamander, crucian carp, and frozen section of the root of horse-radish were used. Horse-radish was used for peroxidase reaction.

Nadi reaction was employed according to the standard technic (SCHUlTZE 1917, WinkLER 1907). In the "Simple Nadi reaction", treatments with Lugol's iodine solution and lithium carbonate were omitted as compared with the standard technic of Nadi reaction.

Benzidine reaction $(\mathrm{Bh})$ : The reagent contains $100 \mathrm{ml}$ distilled water, $0.3 \mathrm{~g}$ benzidine and 10 drops of $3 \%$ hydrogen peroxide.

Orthophenylenediamine reaction (o-p-d) : The reagent contains $100 \mathrm{ml}$ distilled water, $0.1 \mathrm{~g}$ orthophenylenediamine and 10 drops of $3 \%$ hydrogen peroxide.

Paraphenylenediamine reaction (p-p-d): The reagent contains $100 \mathrm{ml}$ hot distilled water and $0.1 \mathrm{~g}$ paraphenylenediamine. After cooling, 10 drops of $3 \%$ hydrogen peroxide are added. Use it immediately.

In general, fixation was carried out with ethanol (9 parts) formol (1 part) mixture for five minutes.

\section{Experimental Results and Discussion}

\section{Inhibition tests}

Potassium cyanide and methanol are known as powerful inhibitors to the peroxidase reaction (Mitsui et al. 1953.). In the present experiment, phenylhydrazine and various aldehycles were examined.

* This work is dedicated to the memory of late Prof. Masaji SEKI, the founder of the Japanese Histochemical Society.

The research reported in this dosument has been made possible through the support and sponsorship of the U.S. Department of Army through its Far East Research Office. 
As shown in Tables 1 and 2, phenylhydrazine hydrochloride inhibited benzidine-, orthophenylenediamine- and paraphenylendiamine reactions at the concentration of $0.01 \mathrm{M}$ (to human eosinophil leukocytes) or $0.001 \mathrm{M}$ (to leukocytes of crucian carp).

Table 1. Inhibition test of peroxidase reaction in human eosinophil leukocytes + (positive reaction) - (negative reaction)

\begin{tabular}{|c|c|c|c|c|}
\hline $\begin{array}{c}\text { phenylhydrazine } \\
\text { hydrochloride, } \\
\text { 5 minutes }\end{array}$ & $\mathrm{pH}$ & $\mathrm{Bh}$ & $\mathrm{o}-\mathrm{p}-\mathrm{d}$ & $\mathrm{p}-\mathrm{p}-\mathrm{d}$ \\
\hline $10^{-1} \mathrm{M}$ & 2.8 & - & - & - \\
$10^{-2} \mathrm{M}$ & 3.0 & - & - & - \\
$10^{-3} \mathrm{M}$ & 3.1 & + & + & + \\
$10^{-4} \mathrm{M}$ & 3.5 & + & + & + \\
$10^{-5} \mathrm{M}$ & 4.0 & + & + & + \\
Control (Water) & & + & + & + \\
\hline
\end{tabular}

Table 2. Inhibition test of peroxidase reaction in neutrophil leukocytes of crucian carp

+ (positive reaction) - (negative reaction) \pm (weak reaction)

\begin{tabular}{|c|c|c|c|c|}
\hline $\begin{array}{c}\text { Phenylhydrazinc } \\
\text { hydrochloride, } \\
\text { 2 minutes }\end{array}$ & $\mathrm{pH}$ & $\mathrm{Bh}$ & o-p-d & p-p-d \\
\hline $10^{-1} \mathrm{M}$ & 2.8 & - & - & - \\
$10^{-2} \mathrm{M}$ & 3.0 & - & - & - \\
$10^{-3} \mathrm{M}$ & 3.1 & - & - & - \\
$10^{-4} \mathrm{M}$ & 3.5 & \pm & \pm & \pm \\
$10-5 \mathrm{M}$ & 4.0 & + & + & + \\
Control (Water) & & + & + & + \\
\hline
\end{tabular}

In this case, the $\mathrm{pH}$ value of the aqueous solution of phenylhydrazine hydrochloride was 3.0-3.1. AsAmI and OzAWA (1963) already reported on the inhibitory action of phenylhydrazine hydrochloride to NADH-enzyme reaction.

The inhibitory action of monoaldehyde (formaldehyde) and dialdehydes to benzidine reaction was compared (Table 3).

Table 3. Inhibition test of benzidine- $\mathrm{H}_{2} \mathrm{O}_{2}$ reaction in human leukocytes with aldehyde solutions + (positive reaction) - (negative reaction) $\pm($ weak reaction $)$

\begin{tabular}{|c|c|c|c|}
\hline Action time 3 hrs & $\begin{array}{c}\text { Final } \\
\mathrm{pH}\end{array}$ & $\begin{array}{c}\text { Eosinophil } \\
\text { leukocyte }\end{array}$ & $\begin{array}{c}\text { Neutrophil } \\
\text { leukocyte }\end{array}$ \\
\hline $\begin{array}{c}\text { Formaldehyde } \\
1 \mathrm{M}(8 \%)\end{array}$ & 7.4 & + & + \\
$\begin{array}{c}\text { Glutaraldehyde } \\
1 \text { M (10\%) }\end{array}$ & 7.2 & + & - \\
$\begin{array}{c}\text { Glutaraldehyde } \\
\text { half M (5\%) }\end{array}$ & 7.2 & + & - \\
$\begin{array}{c}\text { Hydroxyadipic aldehyde } \\
1 \text { M (13\%) }\end{array}$ & 7.3 & + & \pm \\
$\begin{array}{c}\text { Hydroxyadipic aldehyde } \\
\text { half M (6.5\%) }\end{array}$ & 7.2 & + & \pm \\
\hline
\end{tabular}

Molar as well as one half molar solutions of formaldehyde, glutaraldehyde and hydroxyadipic aldehyde were prepared respectively.

Each solution was adjusted to $\mathrm{pH} 7.2-7.4$ with phosphate buffer, and human blood smears were exposed to these aldehyde solutions prior to benzidine reaction. Of these, glutaraldehyde proved to have the strongest inhibitory action although tissue was well fixed with this. Hydroxyadipic aldehyde showed the next strongest inhibitory action, in which case tissue 
was not fixed very well. Formaldehyde showed no inhibitory action under the same condition as glutaraldehyde. It has been well known that formaldehyde is one of the adequate fixatives for blood cells. Considering that glutaraldehyde has been widely used for fixatives of various tissues in electron microscopy, it is worthy of special comment that this aldehyde inhibits the peroxidase reaction more intensely than other aldehydes.

Detailed result of inhibition test of formaldehyde to peroxidase reaction has already been reported by SASAKI (1952), who emphasized that formaldehyde inhibited peroxidase reaction of leukocytes more intensely than ethanol and acetone.

\section{Solubility of reaction end-product}

In cytochemistry, the cells or tissues that are expected to react positively, are generally observed under the microscope, and the positive reaction is identified only when the colored reaction end-product is intensely adsorbed to the cells or tissues. On the contrary, the biochemical peroxidase reaction, where pyrogallol or leucomalachite green is commonly utilized for the substrate, is based on the colorimetric treatment of the colored oxidation product which is homogeneously dissolved in aqueous media. Therefore, if the reaction end-product adsorbed to the cell or tissue, is dissolved during the treatment with water or alcohol, it becomes impossible to determine the result of cytcchemical reaction. Then the solubility of reaction endproduct is an important factor in cytochemical technics.

In the present experiment, the end-product of benzidine reaction $(\mathrm{Bh})$, orthophenylenediamine reaction (o-p-d), paraphenylenediamine reaction ( $p-p-d)$, Nadi and simple Nadi reactions were examined.

As shown in Tables 4 and 5, the endproduct of benzidine reaction is quite stable while that of Nadi reaction is remarkably labile. Especially the end-product of simple Nadi reaction is dissolved in various chemicals. The end-product is regarded as indophenol blue which distinctly appears within the cytoplasm of the myeloid leukocytes. In cyto. chemical reaction, indophenol blue is insoluble in acetone and Cargille's immersion oil (Table 6). However, it is soluble in water and many

Table 4. Solubility of reaction end-product in horse radish

$\mathrm{Bh}$ (benzidine- $\mathrm{H}_{2} \mathrm{O}_{2}$ reaction), o- $\mathrm{p}-\mathrm{d}$ (orthophenylenediamine- $\mathrm{H}_{2} \mathrm{O}_{2}$ reaction), p-p-d (paraphenylenediamine- $\mathrm{H}_{2} \mathrm{O}_{2}$ reaction), + (not dissolved), - (dissolved) \pm (slightly dissolved).

\begin{tabular}{|l|c|c|c|}
\hline Action time 3 hrs & Bh & o-p-d & p-p-d \\
\hline Ethanol & + & + & + \\
Acetone & + & + & + \\
Methanol & + & + & - \\
Glycerin & + & - & - \\
Xylol & + & + & + \\
Water & + & + & + \\
Methacrylate & \pm & + & - \\
\hline
\end{tabular}

Table 5. Solubility of reaction end-product in leukocytes (action time of solvent is $72 \mathrm{hrs)}$ + (not dissolved), - (dissolved), 士 (slightly dissolved).

\begin{tabular}{|l|l|c|c|c|}
\cline { 2 - 4 } & & Ethanol & Acetone & Water \\
\hline $\begin{array}{l}\text { Neutrophil } \\
\text { leukocyte } \\
\text { of salamander }\end{array}$ & $\mathrm{Bh}$ & + & + & + \\
\cline { 2 - 4 } & $\mathrm{o}-\mathrm{p}-\mathrm{d}$ & + & + & + \\
\hline $\begin{array}{l}\text { Eosinophil } \\
\text { leukocyte } \\
\text { of man }\end{array}$ & Nadi & + & + & + \\
\hline
\end{tabular}


chemical substances such as ethanol, methanol, glycerin, xylol, balsam, bioleit (resin for mounting), cedar oil, and apathy gum syrup.

As shown in Table 6, it was found by the present study that the indophenol blue produced by the Nadi reaction became insoluble in many chemical substances mentioned above when the stained blood smear was heated for 5 to 30 minutes in an oven at $150^{\circ} \mathrm{C}$. The indophenol blue is probably oxidized by this heating procedure, and changes in brown substance which is stable to various solvents. These experimental results should always be considered when determining whether human myeloblast is Nadi positive or negative, because Nadi-stained blood smear should not be observed when using immersion oil or balsam before indophenol blue as a reaction end-product is stabilized to these organic solvents.

Table 6. Solubility of reaction end-product in human leukocyte + (not dissolved), - (dissolved), \pm (slightly dissolved)

\begin{tabular}{|l|c|c|c|}
\hline \multicolumn{1}{l|}{} & Simple Nadi & Nadi & $\begin{array}{c}\text { Simple Nadi, } 150^{\circ} \mathrm{C}, \\
5-30 \text { minutes }\end{array}$ \\
\hline Water, 72 hrs & - & + & + \\
Acetone, 72 hrs & + & + & + \\
Ethanol, 72 hrs & - & \pm & + \\
Xylol, half hr & - & - & + \\
Balsam, half hr & - & - & + \\
Bioleit, half hr & - & - & + \\
Ceder oil, half hr & - & - & + \\
Cargille's immersion oil, half hr & + & + & + \\
Glycerin-alum, 2 hrs & - & \pm & + \\
\hline
\end{tabular}

\section{Leuco-eosin method}

Very few applications of the leuco-dye method for oxidative enzymes have been reported except for eosinophil leukocyte, and the dye uscd for this method is limited to some special ones. The authors have attempted to find out other dyes available to this method.

LISON $(1936,38)$ introduced leuco-dye technics as indicators for the peroxidase systems. In the technics, acid fuchsin (LISON 1936) or patent blue (1938) was boiled with powdered zinc and acetic acid until the color of the original dye solution was discharged. With this method hemoglobin and granules of certain leukocytes (eosinophils) are stained distinctly.

It was found by us that eosin can be utilized in place of acid fuchsin or patent blue which were introduced by LisON. The original method of LISON utilized a mixture of dye and comparatively large amount of hydrogen peroxide.

In our technic, however, smaller amount of hydrogen peroxide is used for the demonstration of the peroxidase type.

The solution is prepared as follows: To eosin solution ( $1 \mathrm{~g}$ in $100 \mathrm{ml}$ distilled water) add $10 \mathrm{~g}$ powdered zinc and $2 \mathrm{ml}$ glacial acetic acid. Boil until colorless. Cool and filter.

Before use add to $10 \mathrm{ml}$ of the stock solution one drop of 3 per cent hydrogen peroxide. Stain the blood smear with this reagent for 5 miuutes, and wash in water. Counterstain with hematoxylin or other adequate solution. With this method, erythrocytes and eosinophil leukocytes on blood smear are stained red. 


\section{Conclusion}

In peroxidase reaction of blood cells, greater activity remained after five minutes in formaldehyde at room temperature than in other aldehydes such as glutaraldehyde or hydroxyadipic aldehyde. The end-product of benzidine- $\mathrm{H}_{2} \mathrm{O}_{2}$ reaction was quite stable as compared with that of other reactions.

The end-product of Nadi oxidase reaction was labile to many chemical substances. This end-product, however, changed in stable substance with heating for $5-30$ minutes at $150^{\circ} \mathrm{C}$. The leuco-eosin method was proved to be suitable for the demonstration of peroxidase reaction of eosinophil leukocyte.

\section{酸化系酳素の細胞化学反応に関するニ三の観察（内容自抄）}

塩酸フェニールヒドラジンは $10^{-2}-10^{-3} \mathrm{M}$ の濃度で過酸化酵素反応を阻止する。またグ ルタールアルデヒードおよびハイドロオキシアディピックアルデヒード (dialdehyde) は ホルムアルデヒード (monoaldehyde) よりも同反応の阻止力が大である. Nadi 反応の最終 産物は各種溶媒に不安定であるが, 染色終了後の標本を加熱することにより安定化すとと ができる．また過酸化酵素系に対する leuco-eosin 法の利用価值を論じた。

\section{References}

Asami, K. and H. Ozawa. : Inhibition of mitochondrial NADH oxidase by phenylhydrazine. (in Japanese). Zool. Mag. $72: 269,1963$.

Lison, L. : Histochimie animale. Gauthier-Villars, Paris, 1936, cited from K. Okamoto, et al.: Microscopic histochemistry, Tokyo, Igakushoin, p. 477, 1955.

Lison, L. : Zieglers B. 101 : 94 (1938), cited from K. Okamoto et al. : Microscopic histochemistry, Tokyo, Igakushoin, p. 477, 1955.

Mitsui, T., S. Maruyama, and S. Kamezawa : On the inhibitory action of potassium cyanide upon the cytochemical peroxidase reaction. Fol. anat. jap. $25: 177-188$ (1953).

Sasaki, M.: Influence cf fixatives upon the peroxidase staining. Fol. anat. jap. 24: 193-197 (1952).

Schultze, W. H. : Zentralbl. Pathol. $28: 8$ (1917), cited from G. Gomori : Microscopic histochemistry, Chicago, University of Chicago Press, p. 154, 1952.

Winkler, F.: Der Nachweis von Oxydase in den Leukozyten mittels der DimethylparaphenylendiaminAlphanaphthol Reaktion. Fol. haematol. 4 : 323-328 (1907). 